\title{
A double blind, placebo controlled study of the effects of low dose testosterone undecanoate on the growth of small for age, prepubertal boys
}

\author{
D C Brown, G E Butler, C J H Kelnar, F C W Wu
}

\begin{abstract}
Objective-To assess whether very low doses of testosterone can accelerate growth without an undue advance in bone age in prepubertal boys with constitutional delay of growth.

Subjects-23 prepubertal boys aged 11-14 years with height at or below the third centile for chronological age.

Design-Randomised, double blind trial comparing oral testosterone undecanoate $20 \mathrm{mg}$ once daily versus placebo for six months. The 18 months' observation period of each subject comprised a six month pretreatment period, followed by a six month treatment (testosterone undecanoate or placebo) period, and a six month period after termination of treatment.

Outcome measures-At intervals of six months standing and sitting height were measured. Bone age, pubertal stage, weight, and lean body mass were also determined. Growth hormone, luteinising hormone, and follicle stimulating hormone secretion and testosterone concentration were measured before, after, and six months after treatment.

Results-Boys taking testosterone undecanoate $(n=11)$ showed a significantly greater height velocity (mean (SEM) 5.84 $(0.53) \mathrm{cm} /$ year) and sitting height velocity $(3.54(0.57) \mathrm{cm} /$ year) during treatment than the placebo treated boys $(n=12$, height velocity $=3.38 \quad(0.22) \quad \mathrm{cm} /$ year, sitting height velocity $=1.58 \quad(0 \cdot 19)$ $\mathrm{cm} / \mathrm{year}$. There were no significant differences between the groups regarding changes in growth hormone, gonadotrophins, testosterone, or dihydrotestosterone concentrations. Bone age was not advanced significantly more rapidly in either group.

Conclusions-There is accelerated gain in height during six months of treatment with low dose testosterone undecanoate, without a significantly greater rise in bone age compared with controls. Testosterone undecanoate is a safe, well tolerated, and effective treatment in the management of constitutional delay of growth.

(Arch Dis Child 1995; 73: 131-135)
\end{abstract}

Keywords: testosterone undecanoate, constitutional delay, puberty, growth.

Correspondence to: Dr F C W Wu, Department of Reproductive Medicine, St Mary's Hospital, Hathersage Road, Whitworth Park, Road, Whitworth Park,
Manchester M13 0JH.

Manchester M13 0JH.
Although constitutional growth delay is considered to be a normal growth variant, it remains the most common reason for short stature in boys presenting to endocrine clinics. When such growth delay is accompanied by significant psychosocial impairment and/or educational difficulties, androgen or anabolic steroid treatment has been used to induce a rapid growth spurt. Methyltestosterone, oxandrolone, or fluoxymesterone for six months to several years have been used. ${ }^{1}$ Retrospectively, all these agents improved growth velocity immediately but there was disagreement over whether final height was increased, decreased, or unchanged. More recent trials with low doses of the anabolic steroid oxandrolone ${ }^{2}$ or testosterone oenanthate ${ }^{3}$ for only three months suggested that both were effective in promoting short term growth without unduly accelerating bone growth or compromising predicted final height. In addition, oxandrolone seemed to be able to sustain growth acceleration during the three months after discontinuation of treatment. This, however, was only observed in early pubertal boys and not in prepubertal boys with testes volumes $<4 \mathrm{ml}^{4}{ }^{4}$ This discrepancy may be explained by the fact that oxandrolone augments pituitary growth hormone secretion through a priming effect on the somatotrophs in the pubertal boy whereas in the prepubertal boy this is only observed with testosterone oenanthate treatment. ${ }^{5}$

The aim of the study was to assess whether very low doses of testosterone, as oral testosterone undecanoate $20 \mathrm{mg}$ once daily, could accelerate growth velocity without an undue advance in bone age in boys suffering from constitutional delay of growth. The effects of such treatment on growth hormone and gonadotrophin secretion and testosterone concentration were also monitored.

\section{Subjects and methods}

Twenty three otherwise healthy prepubertal boys with height at or below the third centile for chronological age ${ }^{67}$ with chronological age between 11.0 and 14.0 years and bone age over 8.0 years were studied. Recruitment was from paediatric endocrinology clinics in Edinburgh $(n=17)$ and Cardiff $(n=6)$. These clinics receive referrals from a wide area of the east of Scotland and Wales. After blocked randomisation, using two blocks of 12 , each boy was randomly allocated to receive either two capsules of testosterone undecanoate (Organon Laboratories, Cambridge) $10 \mathrm{mg}$ daily orally for six months or identical placebo capsules. All subjects were observed for a total of 18 months, including six months before and 
six months after treatment. Ethical permission for the study was granted by the paediatric/reproductive medicine ethics of medical research subcommittee of the Lothian Health Board and the child health ethics committee of the South Glamorgan Health Authority. Informed written consent was obtained from each boy's parent(s) after explanation of the procedures involved and provision of printed information. It was noted on the consent form that each child himself had freely consented to participate, and that he and his parent(s) were informed of their right to withdraw. The randomisation code for each patient was broken at the end of the 18 months study period so that further treatment, if any, could be considered.

At screening, a full history and examination for each subject was carried out to ensure that no treatable systemic illness, including endocrinopathy, was present. At intervals of six months height (including sitting height), weight, pubertal stage including axillary and pubic hair stages and testicular volume, ${ }^{8}$ two site skinfold thicknesses (triceps and subscapular), heart rate, and blood pressure were measured. Height and sitting height were measured with a Holtain stadiometer. Standing height to the last completed millimetre was taken with each boy in his bare feet, heels and back in contact with the wall, head held in the Frankfort plane. Subischial leg length was calculated by subtracting sitting height from standing height. Testicular volume was measured by comparison with a Prader orchidometer $^{910}$ and skinfold thickness with Holtain calipers. Only prepubertal boys, defined as having a testicular volume of less than $4 \mathrm{ml}^{11}$ were eligible to enter the study. Lean body mass was calculated from body weight and skinfold thicknesses using the equations of Parizkova. ${ }^{12}$ Radiography of the left hand and wrist with calculation of bone age was carried out at intervals of six months. ${ }^{13}$

Table 1 Growth parameters of study groups, active and placebo, at each assessment

\begin{tabular}{|c|c|c|c|c|}
\hline & Screening & Before treatment & After treatment & $\begin{array}{l}\text { Six months } \\
\text { after treatment }\end{array}$ \\
\hline \multirow{2}{*}{\multicolumn{5}{|c|}{$\begin{array}{l}n=23 \\
\text { Hejght }(\mathrm{cm})\end{array}$}} \\
\hline \multicolumn{4}{|l|}{ Height $(\mathrm{cm})$} & \\
\hline & $130 \cdot 1(1 \cdot 8)$ & $132 \cdot 2(1 \cdot 6)$ & $134.3(1.5)$ & $136 \cdot 3(1 \cdot 6)$ \\
\hline \multicolumn{5}{|l|}{ Sitting height $(\mathrm{cm})$} \\
\hline Active & $67.4(0.8)$ & $68.3(0.9)$ & $70 \cdot 2(0 \cdot 9)$ & $71 \cdot 4(0.7)$ \\
\hline \multicolumn{5}{|l|}{$\begin{array}{l}\text { Placebo } \\
\text { SILL (cm) }\end{array}$} \\
\hline Active & $62 \cdot 2(0 \cdot 7)$ & $63.1(0.9)$ & $64 \cdot 3(0.9)$ & $66 \cdot 1(1 \cdot 0)$ \\
\hline \multicolumn{5}{|l|}{ Weight (kg) } \\
\hline Active & $26 \cdot 4(1 \cdot 0)$ & $27 \cdot 2(1 \cdot 3)$ & $29 \cdot 1(1 \cdot 3)$ & $30.9(1.5)$ \\
\hline $\begin{array}{l}\text { Placebo } \\
\text { Mean testicular volume (ml) }\end{array}$ & $27 \cdot 2(1 \cdot 3)$ & $28 \cdot 4(1 \cdot 0)$ & $30 \cdot 3(1 \cdot 1)$ & $31 \cdot 2(1 \cdot 2)$ \\
\hline $\begin{array}{l}\text { Active } \\
\text { (nin) }\end{array}$ & $2 \cdot 1(0 \cdot 1)$ & $2 \cdot 2(0 \cdot 1)$ & $3 \cdot 1(0 \cdot 2)$ & $4 \cdot 3(0 \cdot 2)$ \\
\hline \multirow{2}{*}{\multicolumn{5}{|c|}{ Axillary hair stage }} \\
\hline & & & & \\
\hline $\begin{array}{l}\text { Active } \\
\text { Placebo }\end{array}$ & $\begin{array}{l}1(0) \\
1(0)\end{array}$ & $\begin{array}{l}1(0) \\
1(0)\end{array}$ & $\begin{array}{l}1(0) \\
1 \cdot 2(0 \cdot 1)\end{array}$ & $\begin{array}{l}1.3(0 \cdot 2) \\
1 \cdot 3(0 \cdot 1)\end{array}$ \\
\hline \multicolumn{5}{|l|}{ Pubic hair stage } \\
\hline $\begin{array}{l}\text { Active } \\
\text { Placebo }\end{array}$ & $1(0)$ & $1(0)$ & $1(0)$ & $1(0)$ \\
\hline$n=17$ & & & & \\
\hline \multicolumn{5}{|l|}{ Lean body mass $(\mathrm{kg})$} \\
\hline Active & & $22 \cdot 7(1 \cdot 1)$ & $23.9(1.0)$ & $24.9(1.0)$ \\
\hline & $23.5(0 \cdot 7)$ & $24 \cdot 5(0 \cdot 4)$ & $25 \cdot 2(0 \cdot 5)$ \\
\hline $\begin{array}{l}\text { Bone age (years) } \\
\text { Active }\end{array}$ & $10 \cdot 2(0 \cdot 4)$ & $11.0(0.4)$ & $11.5(0.4)$ & $12 \cdot 0(0.4)$ \\
\hline Placebo & $10 \cdot 2(0 \cdot 7)$ & $11.0(0.6)$ & $11 \cdot 2(0 \cdot 5)$ & $11 \cdot 7(0 \cdot 5)$ \\
\hline
\end{tabular}

SILL= subischial leg length.
At onset and completion of treatment, full blood indices (Coulter $\mathrm{S}^{+} \mathrm{IV}$ analyser) and biochemical values (Monarch centrifugal, Beckman and Discrete analysers) were measured. At onset of treatment plasma testosterone concentration was measured immediately before and at half hourly intervals for eight hours after the first dose of testosterone undecanoate or placebo. A single morning testosterone concentration was measured after cessation of treatment and six months thereafter. Each subject underwent three sessions of nocturnal blood sampling during which blood samples were withdrawn at 20 minute intervals. Growth hormone, luteinising hormone, and follicle stimulating hormone (FSH) concentrations were then measured for the samples taken during an eight hour period starting one hour after the recorded time of sleep onset. The next morning a $0.25 \mu \mathrm{g} / \mathrm{kg}$ gonadotrophin releasing hormone $(\mathrm{GnRH})$ stimulation test was carried out, and the greatest rise in luteinising hormone and FSH during the following hour recorded. These overnight sessions were carried out shortly before the start, shortly after, and six months after cessation of treatment.

Serum growth hormone was measured using an immunoradiometric assay, calibrated in terms of growth hormone international standard 80/505. The assay employed ${ }^{125}$ I-labelled mouse antigrowth hormone monoclonal antibody (from NETRIA, St Bartholemew's Hospital, London) and polyclonal antigrowth hormone antiserum (SAPU, Carluke) linked to insoluble magnetisable Dynospheres (Dyno Particles AS, Lillestrom, Norway). Internal quality control samples were included (between-batch coefficient of variation $<8.5 \%$ from $2 \cdot 2-49 \mathrm{mU} / 1$ of growth hormone), and performance in the UK national external quality assessment scheme for growth hormone was also satisfactory.

The gonadotrophin assays were performed using Delfia kits (Pharmacia Wallac, Turku, Finland). Fifty microlitres of samples were assayed in duplicate. The within-assay coefficients of variation based on 30 consecutive duplicates of quality controlled pooled plasma samples were $9 \cdot 1 \%, 6 \cdot 3 \%$, and $7 \cdot 1 \%$ for mean hormonal concentrations of $0.24,0.48$, and $0.96 \mathrm{U} / 1$ respectively. The average betweenassay coefficients of variation were $7 \cdot 5 \%$. The mean detection limit of the assay was $0.04 \mathrm{U} / 1$.

Statistical analysis using Student's $t$ test was performed with Microsoft Statworks.

\section{Results}

No subject was withdrawn from the study due to non-compliance (evidenced on direct inquiry or by leftover capsule counts) or side effects. It did not prove possible to collect full data on heart rate, blood pressure, skinfold thickness, bone age, and blood sampling for six of the subjects. Measurements of growth on all 23 subjects were used to calculate velocities of their change during three six month periods: before treatment, during treatment, and after treatment. Growth velocities were 
Table 2 Growth velocities for each treatment group, active and placebo, during each stage of the study

\begin{tabular}{|c|c|c|c|c|}
\hline & $\begin{array}{l}\text { Before } \\
\text { treatment }\end{array}$ & $\begin{array}{l}\text { During } \\
\text { treatment }\end{array}$ & $\begin{array}{l}\text { During six } \\
\text { months after } \\
\text { treatment stopped }\end{array}$ & $\begin{array}{l}\text { During } 12 \\
\text { months after } \\
\text { treatment started }\end{array}$ \\
\hline \multicolumn{5}{|c|}{$\begin{array}{l}n=23 \\
\text { Height velocity ( } \mathrm{cm} / \text { year) }\end{array}$} \\
\hline $\begin{array}{l}\text { Active } \\
\text { Placebo }\end{array}$ & $\begin{array}{l}3.18(0.29) \\
3.31(0.41)\end{array}$ & $\begin{array}{l}5.84(0.53) \\
3.38(0.22) \\
\star p=0.001\end{array}$ & $\begin{array}{l}5.60(0.60) \\
4.62(0.49)\end{array}$ & $\begin{array}{l}5.71(0.35) \\
3.94(0.26) \\
{ }^{\star} \mathrm{p}=0.001\end{array}$ \\
\hline \multicolumn{5}{|c|}{ Sitting height velocity ( $\mathrm{cm} /$ year) } \\
\hline $\begin{array}{l}\text { Active } \\
\text { Placebo }\end{array}$ & $\begin{array}{l}1.61(0.22) \\
1.62(0.23)\end{array}$ & $\begin{array}{l}3.54(0.57) \\
1.58(0.19) \\
{ }^{\star} \mathrm{p}=0.003\end{array}$ & $\begin{array}{l}2.61(0.49) \\
1.38(0.34) \\
\star p=0.048\end{array}$ & $\begin{array}{l}3.00(0.35) \\
1.53(0.20) \\
{ }^{\star} \mathrm{p}=0.001\end{array}$ \\
\hline \multicolumn{5}{|c|}{$\begin{array}{l}n=17 \\
\text { Lean body mass velocity ( } \mathrm{kg} / \text { year) }\end{array}$} \\
\hline $\begin{array}{l}\text { Active } \\
\text { Placebo }\end{array}$ & $\begin{array}{l}0.78(0.68) \\
0.74(0.89)\end{array}$ & $\begin{array}{l}3.36(0.44) \\
3.00(1.34)\end{array}$ & $\begin{array}{l}2 \cdot 12(0.56) \\
1.74(0.67)\end{array}$ & $\begin{array}{l}2.16(0.36) \\
1.82(0.47)\end{array}$ \\
\hline \multicolumn{5}{|c|}{ Bone age velocity (year/year) } \\
\hline $\begin{array}{l}\text { Active } \\
\text { Placebo }\end{array}$ & $\begin{array}{l}1.62(0.4) \\
1.84(0.54)\end{array}$ & $\begin{array}{l}0.84(0.25) \\
0.51(0.34)\end{array}$ & $\begin{array}{l}1 \cdot 16(0 \cdot 27) \\
1 \cdot 15(0 \cdot 26)\end{array}$ & $\begin{array}{l}0.99(0.22) \\
0.77(0.21)\end{array}$ \\
\hline
\end{tabular}

*Significance, Student's $t$ test, active $v$ placebo.

also calculated for the 12 month period after the start of treatment.

Measures of growth parameters for each group at each stage of the study are shown in table 1. Mean (SEM) height velocity $(5 \cdot 84$ $(0.53)$ v $3.38(0.22) \quad \mathrm{cm} /$ year, $\mathrm{p}=0.001$, Student's $t$ test) and sitting height velocity (3.54 (0.57) v $1.58(0.19) \mathrm{cm} /$ year, $\mathrm{p}=0.003)$ were significantly greater in the boys on active testosterone during the six months on treatment (fig 1 and table 2). When growth velocities were calculated for the full year after the start of treatment, the differences between the groups were still significant (height velocity: $5.71(0.35)$ v $3.94(0.26) \mathrm{cm} /$ year, $\mathrm{p}=0.001$; sitting height velocity: $3.00(0.35) v 1.53$ $(0 \cdot 20) \mathrm{cm} /$ year, $\mathrm{p}=0 \cdot 001)$. Bone age velocity was not significantly higher in the testosterone undecanoate treated group during $(0.84(0.25)$ $v 0.51(0.34)$ year/year) or after $(1.16(0.27) v$ $1.15(0.26)$ year/year) treatment. There were no significant changes in vital signs or in haematological or biochemical parameters
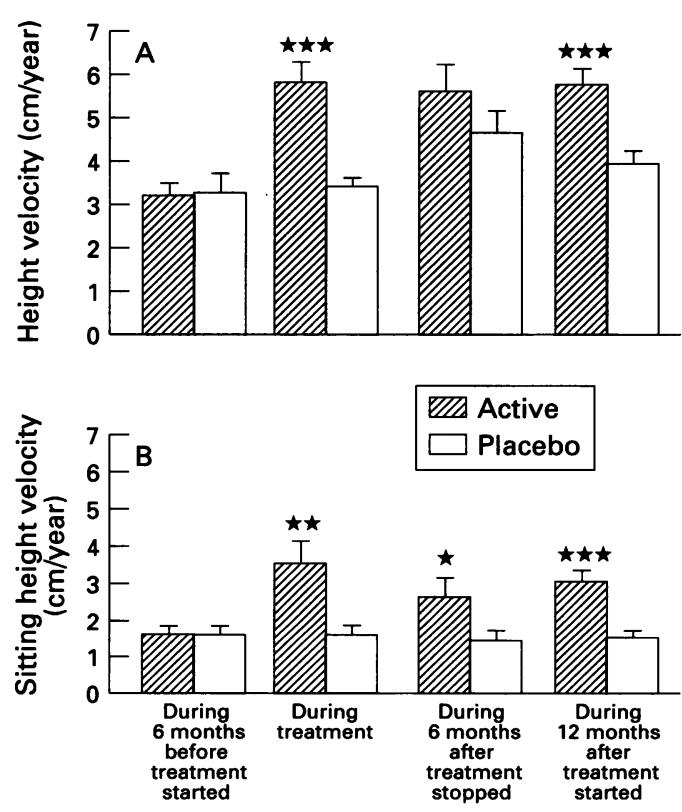

Time period

Figure 1 Mean (SEM) height velocity $(A)$ and sitting height velocity for each treatment group for each study period; ${ }^{\star} p=0.05,{ }^{\star \star} p=0.003,{ }^{\star \star \star} p=0.001$, Student's $\mathrm{t}$ test, active $\mathrm{v}$ placebo.

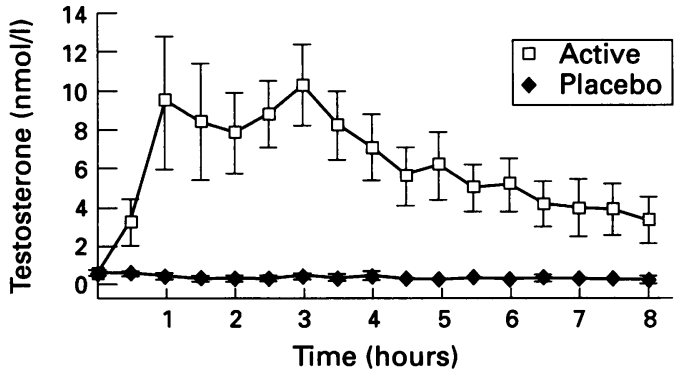

Figure 2 Mean (SEM) testosterone concentrations in treated group after ingestion of first $20 \mathrm{mg}$ dose of testosterone undecanoate $(n=9)$ and in placebo group $(n=8)$.

during treatment. The testosterone absorption studies of the treated group showed a peak concentration of $16.0(2.5) \mathrm{nmol} / \mathrm{l}$, reached at $2.9(0.6)$ hours after ingestion of the first capsules (fig 2).

A summary of mean and maximum nocturnal growth hormone, luteinising hormone, and FSH concentrations, response to $\mathrm{GnRH}$ and early morning testosterone and dihydrotestosterone concentrations during the study are shown in table 3. There were no significant differences between the testosterone undecanoate treated and placebo groups at any stage of the study as regards physiological growth hormone, luteinising hormone, or FSH secretion overnight, GnRH stimulated gonadotrophin rises or early morning testosterone or dihydrotestosterone concentrations.

\section{Discussion}

Short stature can be emotionally disabling and restrain the full realisation of a child's physical and intellectual potential. 1415 The efficacy of anabolic or sex steroids in promoting short term growth and increasing final height is as yet unproved. Carefully designed, controlled, prospective trials to determine the optimum regimen for growth acceleration are of great potential therapeutic benefit to many children. ${ }^{16}$ This study was designed to assess if low dose short term treatment with an orally active androgen can fulfil the therapeutic goal of promoting and sustaining skeletal growth while minimising epiphyseal maturation.

There are disadvantages associated with any relatively short term study of growth. In particular, with regard to studies around the time of puberty, it has been suggested that the evaluation of pubertal growth in pathological situations, and even physically physiological situations such as constitutional delay, should be performed using total pubertal height gain rather than peak height velocity or growth rate which are calculated after a follow up of shorter periods. In general, peak height velocity and/or growth rate are used because most studies are performed and completed before final height has been reached. We could not assess total pubertal height gain because each subject was recruited on the understanding that further or other growth promoting treatment could be instigated on completion of the 18 month assessment period. In addition, 
Table 3 Plasma hormone concentrations for each treatment group, active and placebo, at each stage of the study $(n=17)$

\begin{tabular}{|c|c|c|c|}
\hline & $\begin{array}{l}\text { Before } \\
\text { treatment }\end{array}$ & $\begin{array}{l}\text { After } \\
\text { treatment }\end{array}$ & $\begin{array}{l}\text { During six months } \\
\text { after treatment stopped }\end{array}$ \\
\hline \multicolumn{4}{|c|}{ Growth hormone (mean overnight) (mU/l) } \\
\hline Active & $7 \cdot 44(1.54)$ & $7 \cdot 11(0 \cdot 70)$ & $6.92(0.98)$ \\
\hline Placebo & $6.66(1.37)$ & $8.32(1.58)$ & $7 \cdot 22(1 \cdot 31)$ \\
\hline \multicolumn{4}{|c|}{ Growth hormone (maximum) (mU/l) } \\
\hline Active & $25.63(3.97)$ & $28.61(3.48)$ & $27 \cdot 29(5 \cdot 33)$ \\
\hline Placebo & $28.41(6.56)$ & $37 \cdot 58(7 \cdot 72)$ & $27 \cdot 10(5 \cdot 28)$ \\
\hline \multicolumn{4}{|c|}{ Luteinising hormone (mean overnight) (U/1) } \\
\hline Active & $0.51(0.13)$ & $1.76(0.61)$ & $2 \cdot 34(0.76)$ \\
\hline Placebo & $0.76(0.29)$ & $3.71(1.59)$ & $2 \cdot 17(0.41)$ \\
\hline \multicolumn{4}{|c|}{ Luteinising hormone (maximum) (U/1) } \\
\hline Active & $2 \cdot 21(0.66)$ & $3.96(1 \cdot 19)$ & $4 \cdot 29(1 \cdot 40)$ \\
\hline Placebo & $2.31(0.56)$ & $6.50(2.41)$ & $4.87(0.96)$ \\
\hline \multicolumn{4}{|c|}{ GnRH luteinising hormone rise (U/1) } \\
\hline Active & $3.16(0.75)$ & $8 \cdot 70(2 \cdot 53)$ & $7 \cdot 20(2 \cdot 34)$ \\
\hline Placebo & $3.94(1 \cdot 20)$ & $13.85(5 \cdot 58)$ & $7 \cdot 71(1.02)$ \\
\hline \multicolumn{4}{|c|}{ FSH (mean overnight) (U/l) } \\
\hline Active & $0.48(0.05)$ & $0.93(0.15)$ & $1.38(0.25)$ \\
\hline Placebo & $0.55(0.11)$ & $0.68(0.12)$ & $0.80(0.16)$ \\
\hline \multicolumn{4}{|c|}{ FSH (maximum) (U/l) } \\
\hline Active & $0.79(0.08)$ & $1.65(0.33)$ & $1.99(0.26)$ \\
\hline \multirow{2}{*}{\multicolumn{4}{|c|}{ GnRH FSH rise $(\mathrm{U} / \mathrm{l})$}} \\
\hline & & & \\
\hline Active & $1.91(0.74)$ & $1 \cdot 71(0 \cdot 19)$ & $1.30(0.32)$ \\
\hline Placebo & $1.84(0.48)$ & $1.69(0.28)$ & $1.63(0.28)$ \\
\hline \multicolumn{4}{|c|}{ Testosterone (am) $(\mathrm{nmol} / \mathrm{l})$} \\
\hline Active & $0.55(0.06)$ & $0.35(0 \cdot 14)$ & $0.77(0.27)$ \\
\hline Placebo & $0.50(0.15)$ & $0.36(0.10)$ & $0.68(0.19)$ \\
\hline
\end{tabular}

$\mathrm{GnRH}=$ gonadotrophin hormone releasing hormone.

the object of the study was to assess the growth promoting effects of low dose testosterone undecanoate during and for a six month period after treatment, as the effect in this subgroup of boys, who often present with psychosocial difficulties, would require a fairly rapid effect. In cases of constitutional delay of growth and/or puberty, treatment is not started with an expectation of increased final height. In many cases the latter is unlikely to be compromised without treatment. Treatment offers patients the chance to 'catch up' with their peers' growth spurt. Our calculated results and comparisons deliberately focus on the period of the study only. Speculation on final adult height may be unnecessary for the reasons discussed above. Furthermore, the methods used to calculate a predicted final adult height are dogged with difficulties, particularly around the time of puberty. Final height predictions are less accurate in patients showing marked deviations from the range of physiological variations in height or marked differences between bone age and chronological age. All depend on bone age estimation, which includes errors inherent to reading $x$ ray films and the characteristics of control (in this case placebo treated) children.

The choice of treatment for constitutional delay of growth and/or puberty will depend on a number of factors, ${ }^{17}$ including compliance by the patient and dependable absorption of the preparation. Testosterone undecanoate capsules are small and easily swallowed. In this and previous studies absorption has produced adequate testosterone concentrations within short periods, mimicking the diurnal pattern of physiological testosterone secretion in puberty when the preparation is taken with food in the morning. ${ }^{18-20}$ In studies of boys in early puberty the drug has been administered in higher dose in the evening. ${ }^{21}$

The accelerated gain in height (in particular sitting height) during the six months of treatment, without a significantly enhanced increase in bone age, is an encouraging finding which suggests that even at this low dose testosterone undecanoate taken orally can accelerate height gain and give a much needed psychological advantage to boys in this situation.

Further work is needed to determine the optimum length of treatment. Longer periods of observation would be required to assess the effect on final adult height. In this group of boys, however, final adult height is not the primary concern. As all cases of growth delay have significant bone age retardation, they will usually attain a reasonable adult height without intervention. More often it is the immediate future that concerns these subjects, so that a reasonably rapid acceleration of height gain in the short term can be seen as a positive outcome, provided that it is not accompanied by an excessive acceleration of skeletal maturity. Our results show that testosterone undecanoate is a safe, well tolerated, and effective treatment in the management of constitutional delay of growth.

We would like to thank Susan Barnes and Cathy Sturgeon Wadioimmunoassay (Radioimmunoassay Laboratory, Royal Infirmary of Edinburgh) and Gillian Sutherland and Ian Swanston (Medical Research Council Centre for Reproductive Biology,
Edinburgh) for carrying out the assays, Dorothy Hughes Edinburgh) for carrying out the assays, Dorothy Hughes
(Pharmacy, Royal Infirmary of Edinburgh) for capsule (Pharmacy, Royal Infirmary of Edinburgh) for capsule randomisat

1 Marti-Henneberg C, Niirianen AK, Rappaport R. Oxandrolone treatment of constitutional short stature in boys during adolescence. F Pediatr 1975; 86: 783-8.

2 Stanhope R, Brook CGD. Oxandrolone in low dose for constitutional delay of growth and puberty in boys. Arch Dis Child 1985; 60: 379-81.

3 Rosenfeld RG, Northcraft GB, Hintz RL. A prospective randomized study of testosterone treatment of constitutional delay of growth and development in male adolescents. Pediatrics 1982; 69: 681-7.

4 Clayton PE, Shalet SM, Price DA, Addison GM. Growth and growth hormone response to oxandrolone in boys with constitutional delay of growth and puberty (CDGP) Clin Endocrinol (Oxf) 1988; 29: 123-30.

5 Link K, Blizzard RM, Evans WS, Kaiser DL, Parker MW, Rogol AD. The effect of androgens on the pulsatile release and the 24 hour mean concentration of growth hormone in peripubertal males. $\mathcal{f}$ Clin Endocrinol Metab 1986; 62: in perip.

6 Tanner JM, Whitehouse RH, Takaishi M. Standards from birth to maturity for height, weight, height velocity and weight velocity: British children, 1965. I. Arch Dis Child 1966; 41: 454-71.

7 Tanner JM, Whitehouse RH, Takaishi M. Standards from birth to maturity for height, weight, height velocity and weight velocity: British children, 1965. II. Arch Dis Child 1966; 41: 613-35.

8 Tanner JM. Growth at adolescence. Oxford: Blackwell, 1962. Tanner JM, Whitehouse RH. Clinical longitudinal standards for height, weight, height velocity, weight velocity and stages of puberty. Arch Dis Child 1976; 51: 170-9.

10 Taranger J, Engstrom I, Lichtenstein H, SvennbergRedergren I. Somatic pubertal development. Acta Paediat Scand 1976; 258 (suppl): 121-35.

11 Zachmann M, Prader A, Kind HP, Hafliger H, Budliger H Testicular volume during adolescence: cross-sectional and longitudinal studies. Helvetica Paediatrica Acta 1974; 29: 61-72.

12 Parizkova J. Total body fat and skinfolds in children Metabolism 1961; 10: 794-807.

13 Tanner JM, Whitehouse JH, Marshall WA, Healy MJR Goldstein $\mathrm{H}$. Assessment of skeletal maturity and prediction of
adult height (TW2 method). London: Academic Press, adult 1983.

14 Gordon M, Crouthamel C, Post E, Richman R. Psychosocial aspects of constitutional short stature: social competence, behaviour problems self-esteem and family functioning. $\mathcal{F}$ Pediatr 1982; 101: 477-80.

15 Law CM. The disability of short stature. Arch Dis Child 1987; 62: 855-9.

16 Gregory JW, Greene SA, Thompson J, Scrimgeour CM Rennie MJ. Effects of oral testosterone undecanoate on growth, body composition, strength and energy expenditure of adolescent boys. Clin Endocrinol (Oxf) 1992; 37: 207-13. 
17 Cantrill JA, Dewis P, Large DM, Newman M, Anderson DC. Which testosterone replacement therapy? Clin Endocrinol (Oxf 1984; 21: 97-107.

18 Geere G, Jones J, Atherden SM, Grant DB. Plasma androgens after a single dose of testosterone undecanoate. Arch Dis Child 1980; 55: 218-20.

19 Schurmeyer T, Wickings EJ, Freischem CW, Nieschlag E. Saliva and serum testosterone following oral testosterone undecanoate administration in normal and hypogonadal men. Acta Endocrinol (Copenh) 1983; 102: 456-62.
20 Butler GE, Sellar RE, Walker RF, Hendry M, Kelnar CJH, Wu FCW. Oral testosterone undecanoate in the management of delayed puberty in boys: pharmacokinetics and effects on sexual maturation and growth. $\mathcal{f}$ Clin Endocrinol Metab 1992; 75: 37-44

21 Albanese A, Kewley GD, Long A, Pearl KN, Robins DG Stanhope R. Oral treatment for constitutional delay of growth and puberty in boys: a randomised trial of an anabolic steroid or testosterone undecanoate. Arch Dis Child 1994; 71: 315-7. 